Cuadernos de Historia Moderna

ISSN: 0214-4018

\title{
Obituario
}

\section{José Alcalá-Zamora y Queipo de Llano}

En la noche del 9 de enero de 2019 fallecía D. José Alcalá-Zamora y Queipo de Llano. En momentos como estos en los que los seres humanos tenemos conciencia de que vivir significa también ir recolectando vacíos irreemplazables, me cumple el doloroso honor de trazar una breve semblanza de su brillante y pionero quehacer de historiador. Anárquico y genial en sus múltiples facetas vitales, fue fundador, acaso involuntario, de una escuela en cuyo horizonte intelectual nunca han existido murallas ni trincheras.

Nacido en Málaga el 28 de diciembre de 1939, tanto él como su familia se vieron abocados al exilio tras el final de la Guerra Civil. Su padre, D. Niceto Alcalá-Zamora y Castillo, catedrático de derecho procesal en la Universidad de Santiago desde 1932, fue depurado y separado definitivamente del servicio activo por desafección al régimen franquista el 29 de julio de 1939. El destierro tuvo una primera etapa larga en Argentina; la última la consumó en México a partir de 1945 y duró hasta 1958 cuando sin haber cumplido los veinte años, consiguió volver a España para completar sus estudios universitarios. Al regresar, la vida académica en Madrid no fue fácil y de nuevo las consecuencias derivadas del peso de sus apellidos le obligaron a desplazarse en 1964 a la Universidad de Zaragoza para finalizar la licenciatura y doctorarse. Allí elaboró y defendió su tesis en 1968 que versó sobre la problemática histórica del Mar del Norte a lo largo de la primera mitad del siglo XVII, bajo la supervisión de D. Fernando Solano. También junto a él inició sus primeras tareas como profesor ayudante en la cátedra de Historia Moderna. Tras publicar en 1970 una síntesis de algunos de los resultados de aquella magna investigación en la Revista de la Universidad de Madrid, vio la luz en 1975 la monografía titulada España, Flandes y el mar del Norte (1618-1639): la última ofensiva europea de los Austrias Madrileños. Como él mismo señalaba en el capítulo preliminar, el libro vio la luz a instancias de los profesores Jover Zamora, Díez del Corral y J. H. Elliott y supuso un hito de trascendencia internacional en la renovación de los estudios sobre el siglo XVII hispano y la geopolítica de los Austrias. Dada su vigencia, el Centro de Estudios Políticos y Constitucionales lo reeditó en 2001.

El análisis pormenorizado de algunos de los temas colaterales incluidos en el proceso de aquel trabajo medular, en especial el relativo al desarrollo de la industria de armamento durante la primera mitad del seiscientos, dio lugar a otra serie de investigaciones materializadas en artículos -recopilados en el volumen titulado Altos hornos y poder naval en la España Moderna (Madrid 1999)- y en una monografía excepcional y precursora que de nuevo supuso una innovación en el 
panorama historiográfico español, al fijar su objeto de estudio en el fenómeno de la protoindustrialización ibérica durante la temprana edad moderna. El libro Historia de una empresa siderúrgica: los altos hornos de Liérganes y la Cavada (1622-1834) publicado en Santander en 1974 y de nuevo en 2004, logró modificar las versiones admitidas sobre la nula adopción de los métodos vanguardistas de la metalurgia en España y es hoy referencia inexcusable para los investigadores de los avances técnicos y de la economía peninsulares antes de la era industrial.

Estos y otros trabajos junto a su labor docente, permitieron a Alcalá-Zamora consolidar su posición en la universidad española primero en 1977 como profesor agregado y sucesivamente como catedrático de Historia Moderna en Murcia, la UNED y finalmente, en 1982, en la Complutense de Madrid donde ejerció la docencia hasta su jubilación.

En sus clases supo despertar el entusiasmo por la investigación en las áreas de estudio que frecuentaba, tanto entre los alumnos como entre los jóvenes profesores con los que convivía en el Departamento de Historia Moderna y a los que coordinó en la elaboración de otra de las obras de Historia Social que resultó pionera en la divulgación histórica de calidad y que bajo el título La vida cotidiana en la España de Velázquez, tuvo un notable éxito y dos ediciones en 1989 y 1999. Para entonces Alcalá-Zamora había sido elegido miembro de la Real Academia de la Historia con 48 años, convirtiéndose en el miembro más joven de la corporación que lo había escogido con la intención, como diría su presentador Don Gonzalo Anes, "de que 'la pirámide de edades' de la Academia se fuera ensanchando por la base". Su discurso de ingreso, convertido poco después en una monografía de referencia de la, por entonces, novísima historia cultural, versó sobre La Reflexión política en el itinerario del teatro calderoniano, y era síntesis de sus inquietudes en materia literaria alrededor de la biografía no sólo creativa sino también política, de Calderón de la Barca sobre el que volcó con ahínco su inteligente curiosidad. En los albores del tercer milenio organizó el congreso internacional Calderón de la Barca y la España del Barroco y coordinó la edición en Castalia, junto con Díez Borque, de las "Obras Maestras" calderonianas. También publicó el volumen recopilatorio de sus trabajos fragmentarios sobre este tema titulado Estudios Calderonianos. Son sólo algunas muestras sobresalientes del vivo interés que mantuvo a lo largo de toda su vida por la comprensión de aquel genio literario universal y de su producción en el contexto político y sociocultural en el que surgió.

Cuando cesó la actividad de Alcalá-Zamora como profesor universitario en 2007, sin agotar el plazo del retiro laboral y fiel al espíritu libre que presidió su vida, confesaba hallarse muy lejos de una universidad en la que, según su interpretación, la burocracia había ganado la partida al magisterio y al talento creativo. Volcó a partir de entonces sus energías en todas aquellas otras facetas que fueron consustanciales a su persona y que han quedado marginadas en esta semblanza a pesar de correr paralelas e indisolublemente unidas en el tiempo a su actividad académica. No me hubiera perdonado no recordarlas. Buen jugador de ajedrez y excelente tirador de armas antiguas, su vocación literaria quedó materializada en una treintena de libros de poesía editados entre 1965 y 2015 que le consagraron como un consumado, prolífico y premiado sonetista. También su peculiar perfil de triatleta y corredor de fondo con más de una treintena de maratones a sus espaldas, finalizados con excelentes tiempos, dan prueba de su inquebrantable espíritu deportivo. 
Con su fino y omnipresente sentido del humor supo vadear la dureza de los últimos días y al recrear en la imaginación el trance doloroso que supondría su pérdida para todos los que le queríamos, declaraba:

La vida ha sido larga, no me quejo ni de su duración ni de su fruto.

No llevéis, si me voy, penas ni luto, hay que morirse, sin saberse viejo'.

En definitiva hemos perdido a un gran historiador de personalidad rica y enriquecedora, enérgica y compleja, irrepetible y sobresaliente. Descanse en Paz, D. José Alcalá-Zamora; mi maestro.

Carmen Sanz Ayán Real Academia de la Historia \& Universidad Complutense de Madrid 